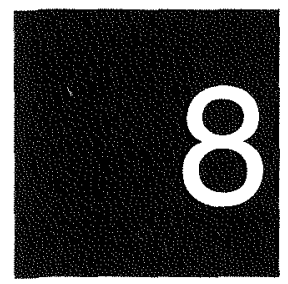

\title{
Property, sovereignty and self-determination in Australia
}

\section{Henry Reynolds}

The concept of national sovereignty is under siege in many parts of the world as states lose power from above to global markets and global organisations and are challenged from below by regions, minorities and entrapped nations. Such developments are particularly apparent in Europe with the break-up of the Soviet Union, Yugoslavia and Czechoslovakia, and with the ceding of power within the European Union to the Commission, the Parliament and the Court. At the same time regions are asserting new or rediscovered identities.

John Keane, the British political scientist and biographer of Thomas Paine, has called for a decentring of the institutions of the nation-state and the return to the more complex pattern typical of the late medieval and early modern periods when Europe was divided into 500 or so political units (Keane 1992:10). Two other commentators have recently advanced arguments of more direct relevance to the Australian scene. The French philosopher Paul Ricoeur observed that 'in modern republics, the origin of sovereignty is in the people, but now we recognise we have many peoples. And many people mean many centres of sovereignty...' (Ricoeur 1995:35).

The second argument was put forward by the prominent British Conservative politician Geoffrey Howe who wrote 
I believe sovereignty is not some pre-defined absolute, but a flexible, adaptable, organic notion that endures and adjusts with circumstances...In exactly the same way as property rights of an individual, sovereignty may be seen as divisible and exploitable in the interests of the nation (Howe 1990:679).

To date Australia appears to be untroubled by debates about the nature, extent and the exercise of sovereignty. Aboriginal challenges to absolute Crown sovereignty have been summarily dismissed by Australian judges. The traditional view was reaffirmed by the High Court in the Mabo case as was the so-called Act of State doctrine which upholds the view that an extension of sovereignty is an act of prerogative power which cannot be questioned by the courts.

Two key assumptions underpin the conventional view about the imposition of British sovereignty over Australia. They relate to sovereignty itself, on the one hand, and to traditional Aboriginal society on the other.

The traditional British view of sovereignty was summed up by William Blackstone in his classic work Commentaries on the Laws of England, published just before the first settlement of Australia. Blackstone argued that in any state there must be 'a supreme, irresistible, absolute, uncontrolled authority' (Blackstone 1773, 1:30). It was this view of authority which was brought to Australia where it was commonly believed there was no government, no law and no ownership of land in the sense understood by Europeans. Several things followed from this situation.

- British sovereignty in Australia was original, not derivative

- the Crown was therefore both the first and only sovereign

- sovereignty applied immediately and everywhere in the absence of any competing sovereign.

But how did this concept of the Crown's sovereignty relate to the idea of terra nullius? In the Mabo case the High Court rejected the idea in relation to property while confirming it in relation to sovereignty. The bench determined that, contrary to previous assumptions, the aboriginal tribes were in possession of their traditional lands. They had a form of customary tenure. When the Crown annexed Australia it acquired the radical title but not the beneficial ownership of the land which remained in the possession of the indigenous people. Much land was lost by extinguishment but it happened in a piecemeal 
fashion over a long period of time. Native title had survived on Murray Island because nothing the Queensland government had done between 1879 and 1992 had extinguished it. Traditional Murray Island property law survives as part of the common law. It is the local law, the lex loci of that place.

What we have now, then, is two stories in conflict. Terra nullius applies in respect of sovereignty, but it has been overthrown in relation to property. Can this situation be sustained? Must there be a new jurisprudential story which treats sovereignty in the same way as property? What would that story be like?

1. Before 1788 the Aborigines and Torres Strait Islanders exercised a form of sovereignty, albeit rudimentary, over their traditional territories. The tribal groupings, however defined, were small nations.

2. The original British claim of sovereignty by discovery was a claim of priority against rival European powers. It was a claim for external sovereignty only.

3. Within Australia, sovereignty was asserted very slowly as settlement advanced gradually over the vast land mass.

4. Colonial Australia had many sovereigns and many systems of law although there were far fewer in 1900 than in 1800.

5. Remnant sovereignty survives among those communities which still exercise traditional law.

What we have, in sum, is a typical colonial situation where the common law applied but only as the circumstances of the colony allowed. This brings us back to Geoffrey Howes' view that sovereignty was imposed, in practice in a complex way and that in Australia it changed considerably over the colonial period.

Such a new story would have major implications for Australian law and Australian politics. It would dramatically change the relationship between indigenous Australians and the state. It suggests that like the First Nations of Canada the Aborigines and Islanders have an inherent right to self-government arising from the survival of their original sovereignty.

In seeking to find support for self-determination indigenous Australians will turn not just outward to international law and documents but also inward to our own society and backward to our own historical experience. 


\section{References}

Blackstone, W., 1773. Commentaries on the Laws of England, 4 vols, 5 th ed., Clarendon Press, Oxford.

Howe, G., 1990 'Sovereignty and Interdependence: Britain's place in the world', International Affairs, 66(4):675-95.

Keane, J., 1992. 'Democracy's Poisonous Fruit', Times Literary Supplement, 21 August:10.

Ricoeur, P., 1995. 'Universality and the power of difference', in R. Kearney (ed.), States of Mind: dialogues with contemporary thinkers, New York University Press, New York:33-8. 